\title{
How Can Environmental Pollution by Ships be Minimized at the New Terminal of Cargo Offloading Facility of the Caspian Sea?
}

\author{
Sarvar Khalikov ${ }^{1,2}$, Altynbek Smailkhan' ${ }^{1}, K^{2}$ ila Nukuyeva ${ }^{3}$ \\ ${ }^{1}$ College of Transport \& Communications, Shanghai Maritime University, Shanghai, China \\ ${ }^{2}$ Uzbek State University of World Languages, Tashkent, Uzbekistan \\ ${ }^{3}$ Kazakhstan Maritime Academy, Kazakh-British Technical University, Almaty, Kazakhstan \\ Email: kh.sarvar@bk.ru,smailkhan.a@gmail.com,kamila_nukueva@mail.ru
}

How to cite this paper: Khalikov, S., Smailkhan, A., \& Nukuyeva, K. (2020). How Can Environmental Pollution by Ships be Minimized at the New Terminal of Cargo Offloading Facility of the Caspian Sea? Journal of Geoscience and Environment Protection, 8, 28-45.

https://doi.org/10.4236/gep.2020.81003

Received: December 24, 2019

Accepted: January 7, 2020

Published: January 10, 2020

Copyright $\odot 2020$ by author(s) and Scientific Research Publishing Inc. This work is licensed under the Creative Commons Attribution International License (CC BY 4.0).

http://creativecommons.org/licenses/by/4.0/

(c) (i) Open Access

\begin{abstract}
Nowadays pollution from ships in ports/terminals of the Caspian Sea has a significant impact on surrounding nature and health. And the Kazakh oil company "Tengizchevroil" is about to realize a new big business project in terms of water area, which might lead to increased pollution. So, this research specifically concentrates on the reduction of environmental pollution problems at the new Terminal of Cargo Offloading Facility and Cargo Transportation Route of the North Caspian Sea. In order to reach this motive, the authors analyze IMO's International Convention for the Prevention of Pollution and its initial strategy on reduction of GHG emissions from ships. In addition, efficiency of shore power supply, which is often used by developed countries for better environmental conditions for the port area, is also examined. Overall, the authors outline six proposals as to the best course of action, which needs to be implemented at the new Tengizchevroil terminal. The items such as calculation of damage and calculation of prices of pollution prevention measures will not be included in the research.
\end{abstract}

\section{Keywords}

Kazakhstan, North Caspian Sea, MARPOL, GHG Emission, Air Pollutants, Shore Power Supply

\section{Introduction}

At one of the key oil-fields of Republic of Kazakhstan, Tengiz (Figure 1), the shareholders of joint company Tengizchevroil started to implement a new large-scale project in order to expand extraction of oil capacities. The project is 


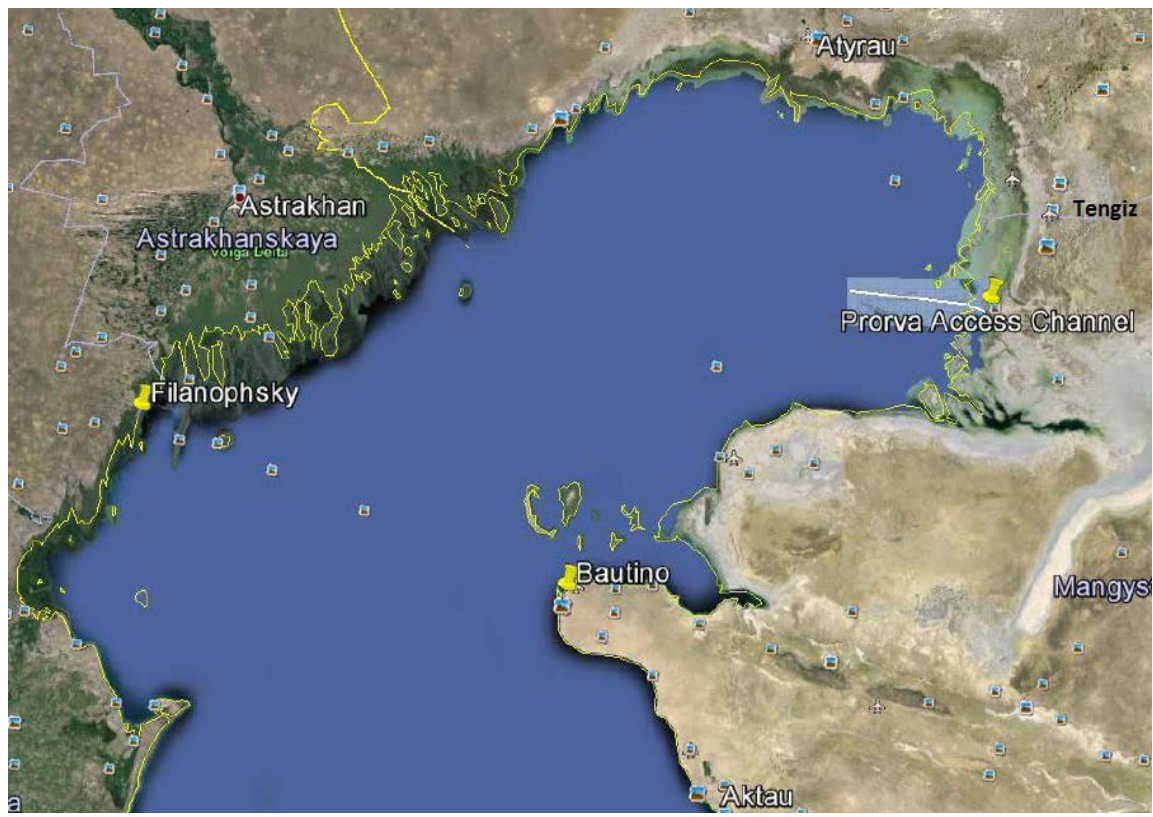

Figure 1. North Caspian Sea.

called the Future Growth Project (FGP). Due to the implementation of the FGP, the volume of oil production at the Tengiz oil-field will increase from 25.9 million metric tons (207 million barrels) to 38 million tons per year. The facilities for the FGP will be built up in the field's operational territory, located in northwestern Kazakhstan's low-lying wetlands along the northeast shores of the Caspian Sea, which can be seen from the map of the North Caspian Sea (Figure 1). In particular, the facilities to be built include: 1) the FGP's oil-gathering system, including production wells, metering units, and modular collectors; 2 ) the pressure increasing systems (input separators, a pump unit, and a compressor unit); 3) a plant for processing and treating oil and gas for injection into reservoirs, and systems for electricity generation; 4) a compressor station for sour gas injection into reservoirs.

Construction is planned on a so-called modular method. Because of the uniqueness of FGP equipment, modules are pre-assembled by the manufacturer in big modules, which are transported to the destination point. Module Carrying Vessels (MCV) were built to transport modules to TCOF Prorva, through Cargo Transportation Route (CaTRo). In addition to this purpose-built tug boats deployed in the Caspian Sea to assist MCV in transport and navigational operations. Modules are assembled in Kazakhstan, South Korea, and Italy. Fabricated modules then shipped through the Russian Inland Waterway System into the Caspian Sea for final delivery to the new Terminal of Cargo Offloading Facility (TCOF) in Prorva peninsula near the Tengiz oil-field. The modules are then transported by road transport to the oil-field. And the problem statement is that there is an environmental risk in the TCOF area and in the CaTRo channel due to the nature of the maritime activities carried out by Tengizchevroil and its new project. 
The Northeast Caspian is an area that includes globally important biodiversity features. The area of CaTRo channel is a domicile for different birds, fishes, and other fauna. Especially there we can find sturgeons and Caspian seals, which are endangered because of different sea operations (Dmitrieva et al., 2013). So, extra attention should be paid by vessels during operations in this area, as the rare Caspian seals are found only in this sea. Especially, due to the implementation of FGP and operations in TCOF and in CaTRo channel of the Caspian Sea, pollution of the environment should be minimized as more as possible. Environmentally friendly technologies for the processing of these activities are expensive and there can be a risk that they are not used in some regions. TCOF should be provided with environmentally friendly facilities in order to safeguard, it's surrounding area like usual ports and vessels should pay extra attention to sea habitats during operation in the CaTRo channel. So, despite the fact that FGP will help in the construction of new oil-field in Kazakhstan, it can endanger the environment, as it has a lot of facilities, operations, and works done every day which effect on the environment negatively.

The main objective of the study is to find an answer to the following question: How can environmental pollution by ships be minimized at Cargo Offloading Facility of the Caspian Sea? The possible future measures to the issue are given in Section 5 of the paper. However, the present situation on the environmental protection in TCOF and CaTRo is provided in Section 4. Section 3 aims to identify all the causes of pollution from ships.

\section{Project Scope \& Methodology}

The scope of the project is limited to TCOF area and CaTRo channel. It is directed to evaluate the overall picture of ecological and environmental problems of the Caspian Sea, specifically in the TCOF area, caused by ships. The items such as calculation of damage, calculation of prices of pollution prevention measures and identification of the reasons of pollution other than pollution by ships will not be included in the research.

This project is mainly focused on the environmental and ecological aspects of TCOF area. The literature review of the research is based on the different national and international regulations regarding the prevention of pollution by ships, company information, and articles related to pollution by ships in port areas. As there is no specific literature for the analysis of pollution by ships in port areas, a few books, regulations and scientific works were analyzed. This includes the regulations as "Environmental Management Systems" and "Environmental Code of the Republic of Kazakhstan", "International Convention for the Prevention of Pollution (MARPOL)"; the plans as "Shipboard Oil Pollution Emergency Plan" and "Ballast Water Management Plan". The main information about the current situation regarding the environmental protection in the TCOF area is collected by personal reviewing company reports which are collected from FGP authorities. 


\section{Causes of Pollution by Ships and Dangers Raised from That}

According to the study made by International Transport Forum in 2014, between $70 \%$ to $100 \%$ of emissions in ports in developed countries can be attributed to shipping, trucks, and locomotives represent up to one fifth, whereas emissions from equipment rarely exceed 15\% (Merk, 2014). And as mentioned previously, this chapter identifies and describes the environmental impact of shipping such as include water pollution, air pollution, land pollution, noise pollution, environmental effects on flora/fauna, etc.

\subsection{Gas Emissions}

Air pollution is one of the concerns in port areas. Air is impacted by air emissions due to ship's operations at the port. The diesel fuel vessels are the number one source for emissions of nitrogen oxides $\left(\mathrm{NO}_{\mathrm{X}}\right)$, sulfur oxides $\left(\mathrm{SO}_{\mathrm{X}}\right)$, particulate matter (PM), carbon monoxide (CO), and air toxics at port facilities (U.S. Environmental Protection Agency, 2018).

The source, which is making our planet heat, is GHG. "Human activities are the primary source for almost all of the increase in greenhouse gases (GHG) in the atmosphere over the last 150 years" (Mackay, 2008). Mainly burning fossil fuels for electricity, heat, and transportation are considered a prime cause of emissions.

- Transportation, transportation produces the largest amount of GHG emissions. Those emissions produced from the burning of fossil fuel for our cars, ships, trains, trucks, and planes. Specifically, diesel engines are the most dangerous GHG source.

- Electricity production, electricity production generates the second largest amount of GHG emissions. Approximately 62.9 percent of our electricity comes from burning fossil fuels, mostly coal and natural gas (U.S. Energy Information Administration, 2019).

- Industry, these emissions are mainly come from burning fossil fuels for energy, as well as GHG emissions from particular chemical reactions which are necessary for the production of goods from raw materials.

Effect of air pollution. The use of diesel engines and other engines in and around ports can contribute to decreased air quality and related health impacts for community residents. Air pollution has an effect on human health in several ways. Some scientific studies have linked air pollution to a variety of health problems which can include cancer, heart problems (Vidal, 2009), negative impacts on the nervous system, including the brain, deterioration of respiratory and cardiovascular illness; reduction of the lung function; respiratory symptoms; increased sensitivity to respiratory infections; and premature death.

Some people who sensitive to harmful emissions are at greater risk for air pollution-related health effects. For instance, those with pre-existing heart and lung diseases (e.g., heart failure/ischemic heart disease, asthma, emphysema, and 
chronic bronchitis), diabetics, older adults, and children. Air pollution also damages our environment. For example, ozone can damage vegetation, adversely impacting the growth of plants and trees. These impacts can reduce the ability of plants to uptake carbon dioxide $\left(\mathrm{CO}_{2}\right)$ from the atmosphere and indirectly affect entire ecosystems.

\subsection{Spills}

The spills from ships can be accidentally thrown overboard during ships staying at the port. Those spills can have an enormous effect on the water quality and the state of marine life. Waste from vessels and other port activities can lead to the loss or reduction of habitat areas and can also bring harm to marine life. The operations which can accidentally provoke spill are sewage, bilge water, ship's paint, oil spills and solid waste.

Sewage is wastewater from toilets, sinks, showers, galleys, laundry, medical facilities, and cleaning facilities aboard a ship. This wastewater can contain harmful bacteria, pathogens, viruses, intestinal parasites, harmful nutrients, and pollutant substances such as detergents, oil, grease, metal, organic compounds, food waste, medical and dental waste. Discharges of untreated or inadequately treated sewage can cause bacterial and viral contamination of fisheries and shellfish beds, producing risks to public health. Nutrients in sewage, such as nitrogen and phosphorus, promote excessive algal blooms, which consumes oxygen in the water and can lead to fish kills and destruction of other aquatic life (Sheppard, 2018).

Bilge water. On a ship, oil often leaks from engine and machinery spaces or from engine maintenance activities and then mixes with water in the bilge. In addition to this bilge water may comprise solid wastes and pollutants which contain high-level of oxygen-exacting materials, oil, and other chemicals. Despite that bilge water is filtered and cleaned before being discharged, oil in even minute concentrations can kill fish or have various sub-lethal chronic effects.

Ship's paint. Lixiviation of toxic paint impurities, meant to prevent barnacles from clinging to ships, can result in health impacts on marine life.

Oil impurity can include chronic pollution from runoff, bilge water, and the cargo operations of oil tankers, additionally huge spills resulting from overfilling of tanker ships or tears in a ship's hull.

The solid waste generated on a ship includes glass, paper, cardboard, aluminum and steel cans, and plastics. It can be either non-hazardous or hazardous in nature. Marine mammals, fish, sea turtles, and birds can be injured or killed from entanglement with plastics and other solid waste that may be released or disposed off from ships.

\subsection{Incinerator}

As much as 75 percent of solid waste is incinerated on board, and the ash typically is discharged at sea. Burning of solid wastes is dangerous for marine life and human health. Burning plastic and other wastes release dangerous sub- 
stances such as heavy metals, Persistent Organic Pollutants, and other toxins into the air and ash waste residues. Such pollutants contribute to the development of asthma, cancer, endocrine disruption, and the global burden of disease. In addition to this, it is bad for the climate and oceans. Plastic is a petroleum-based material, and when burned its like any other fossil fuel: it releases climate pollution. This, in turn, leads to rising sea levels, increased ocean and air toxicity, and destruction of coral reefs and other marine life.

\subsection{Human Factor}

One of the reasons for the contamination of the environment is the negligence of crew about the environment. Sometimes the crew does not understand that the pollution must be prevented and nobody controls and punishes them. Besides, some people believe that the Caspian Sea is huge enough and if they dump contaminants overboard, nothing will happen to the environment. It means crew doesn't know all the seriousness of pollution of the environment by the contaminants which were discharged by their ship.

\subsection{Noise}

The noise, which is produced by ships can travel long distances, and marine species who may depend on sound for their orientation, communication, and feeding, can be harmed by this sound pollution. The Convention on the Conservation of Migratory Species has identified marine noise as a potential threat to marine life. Besides, light and noise pollution from port operations can result in a lower quality of life and health impacts for community residents.

\subsection{Dredged Channel}

Removing sediment in order to deepen ship channels can raise the cloudiness of water and bother contaminated bottom sediment, make harm or permanently destroy critical wildlife habitats, and disturb or kill threatened and endangered species.

\subsection{Ballast Water}

Ballast water can contain a variety of biological materials, including plants, animals, viruses, and bacteria. These materials often include non-native, nuisance, invasive, exotic species that can cause extensive ecological and economic damage to aquatic ecosystems along with serious human health problems.

\subsection{Wildlife Collision}

The Caspian Seal, which is one of the smallest seals in the world can be in danger because of different sea operations. The Caspian seal is native to the Caspian Sea and its population has decreased by more than $90 \%$ since the start of the 20 th century. According to the UK Government Darwin Initiative \& the Kazakh Fisheries Research and Production Centre (2006), "the population continues to 
decline due to threats arising from human impacts on the Caspian Sea ecosystem, and the species is now listed as endangered on the International Union for Conservation of Nature red list".

\subsection{Concluding Marks}

Environmental pollution might be caused by various factors and it can impact human health as well as flora and fauna. For the purpose of this research, the cause and effect relation were done, which is Appendix 1 of this work, in order to simplify the understanding of the reader about the consequences of pollution. International Convention for the Prevention of Pollution from Ships (MARPOL) (Julian, 2000) and Environmental Code of Republic of Kazakhstan was created to regulate the aforementioned issues with emission.

\section{Current Situation at TCOF Regarding Environmental Protection}

It is necessary for the research to understand the present situation on the environmental protection for answering the main question. This chapter describes what is currently done in the TCOF area to protect the surrounding nature. First of all, in order to minimize the risk of environmental pollution, vessels shall comply with the requirements of the MARPOL and with the legislation of Republic of Kazakhstan (RKz):

\subsection{Minimize Pollution by Ballast Water}

- Vessels shall comply fully with the International Convention for the Control and Management of Ships' Ballast Water;

- After commencing to discharge any ballast to the sea, an overside inspection of the sea surface shall be made;

\subsection{Noise, Light, Vibration}

- The noise level on board of new and existing vessels should satisfy International Maritime Organization (IMO) Resolution A.468 (XII) "Code on noise levels on board ships";

- Maintenance activities which require the opening of equipment spaces and equipment space doors/gratings/covers, allowing increased noise and vibration levels, shall not be carried out in the CaTRo Channel;

- Maintenance activities carried out in the CaTRo shall be limited to those activities that will not generate percussively and impulse noise generation;

- Night time on deck (external) maintenance shall be restricted to activities not requiring additional artificial light sources (light sources not provided by normal vessel operations for night time working);

- Regular inspections of vessel external lighting shall be conducted to ensure light fittings are positioned as installed, the light spill is reduced, and no unnecessary lights are being utilized; 
- Where safe to do so (such as in the galley/cabins) blinds will be closed to reduce light spill;

- The vessel horn shall only be sounded in accordance with vessel safety protocols and not used unnecessarily e.g. as a greeting for passing vessels.

\subsection{Spills}

- In case of an oil spill, vessels shall comply fully with the Shipboard Oil Pollution Emergency Plan;

- Bilges and other spaces likely to be contaminated with oil residue etc. shall not be pumped overboard;

- The bilge oily water separator overboard discharge valve shall be locked in the closed position;

- Vessels equipped with a functioning IMO compliant sewage treatment plant may NOT discharge overboard. All Sewage shall be retained on board;

- Vessels shall take every precaution to prevent the release of oil, noxious liquid substances, garbage, sewage, polluted ballast waters into the waters of the Caspian Sea;

- If an emergency arises and discharges are made to maintain the ship's stability, the time, and approximate amount of the discharges shall be logged along with the circumstances requiring the action.

\subsection{Incineration}

- Incinerators may not be used when a vessel is alongside any of the TCOF berths.

\subsection{Fauna}

- Vessel operation and crew activities are required to avoid if possible interactions with fauna. Typically, this is Caspian Seal and migratory or resident bird life. Fauna must not see vessels as a potential source of food or refuge;

- In the CaTRo Channel vessel speed restriction of max 15 knots will allow seals to anticipate and maneuver away from vessels;

- It is strictly prohibited for Partners personnel, visitors and members of vessel crews to feed wildlife. Galley foodstuff e.g. dry goods shall not be stored on decks. Where it is not practical to do so food containers shall be kept closed and or securely covered. Any spillages shall be cleaned away immediately and if required residues washed or swept clean. Food shall only be consumed other than in the galley mess area or designated internal locations;

- It is strictly prohibited for vessel crew or passengers to fish or hunt fauna at any point in vessel operations. Equipment used for fishing and hunting shall not be allowed on vessels;

- It is possible that bird life could land on vessels. No attempt shall be made to capture animals in these circumstances, this applies even if the animal appears ill or injured. As far as is possible for the safe operation of the vessel the area should be avoided by the crew. In the event the sick or injured bird is 
preventing safe operations it will be moved by a member of the vessel crew to an alternative less intrusive location.

\subsection{Report}

- Any pollution by a vessel alongside must be reported immediately to the VTMS Operator. Immediate measures to stop the cause and limit the extent of the pollution must be taken;

- Any interactions with fauna shall be recorded in the vessel log and reported by the Vessel Master to the Client;

- Any incident causing harm to the environment must be reported as soon as detected to VTMS Control. Any oil spill on water, regardless of the TIER level, must be communicated by radio immediately.

\subsection{Responsibilities}

- Master of the vessel: the Vessel Master is the main Authority and is responsible for the safe conduct of marine activity on-board his vessel and has the right to decide to stop ongoing navigation and/or operations, whenever he deems a possible risk for the vessel, crew or environment may arise. The Master is also responsible for complying with the requirements of the TCOF Authority and RKz regulations;

- The Master and Owners must accept that all the costs associated with clean-up of any pollution incident attributed to the ship will be to the owner's account. This includes but is not limited to, oil pollution response and clean up, pollution prevention and any contingency where there is an increased risk of pollution over and above that for normal TCOF operations.

\subsection{Services Provided}

Local authorities provide various services in order to assist the vessels in their operations, these facilities include shallow draft vessel, bunkering operations, oil spill response (OSR) vessel and the reception of waste, sludge, sewage.

OSR vessel most attracts attention, as it is often used during Emergency Spill Response Operation in Prorva TCOF. OSR vessel shall be able to clean sea surface and shore for all kinds of oil spills, to collect other debris during oil spills and/or to clean the port during standby duty.

Next in line is shallow draft vessel, which is used for the survey-bathymetric work. It means to determine seabed conditions, sea depths (bathymetry), side scan sonar survey, etc.

Bunkering operations: during this procedure, the proper hose management shall be present in order to minimize risk to the environment and people and mitigate the risk of a spill. The hoses shall be equipped with TODO-MATIC dry-break couplings.

In addition to all these facilities, there should be always available supply vessels for emergency situations. According to the interview taken from Tengizchevroil workers, who are the main stakeholders of FGP, "the authorities of FGP 
provide all means possible for vessels operating in this area to minimize the pollution. All works conducted in the TCOF area cover full aspects of safety and security so that not cause any damage to the environment. They conduct absolute control regarding all operations by vessels".

\section{Possible Measures to Minimize Pollution}

There are regulations which must be followed by vessels in order to minimize pollution. Specifically, international conventions set the standards for the port and vessels to play down the pollution by ships. In addition to this, some countries consider additional measures for the prevention of pollution.

\subsection{International Maritime Organization}

IMO is the United Nations specialized agency which is responsible for the safety and security of shipping and the prevention of marine and atmospheric pollution by ships. It is involved in the projects which are aimed to reduce pollution, it sets the regulations and engaged in the implementation of those regulations.

\subsubsection{MARPOL}

MARPOL is one of the most important international marine environmental conventions. It was developed by IMO in order to minimize pollution of the oceans and seas, including dumping, oil, and air pollution. Initially, MARPOL was signed on 17 February 1973 but did not come into force right away. The current version of MARPOL is a conjunction of 1973 Convention and the 1978 Protocol, which entered into force on 2 October 1983 (Julian, 2000). Nowadays 156 states are the parties to the MARPOL convention, being flag states of $99.42 \%$ of the world's shipping tonnage. All ships which are flagged under countries that signed MARPOL are subject to its regulations, regardless of where they sail and member nations are responsible for vessels registered on their national ship registry. Nowadays Kazakhstan is the signatory of MARPOL's first 5 Annexes, the Annex VI is not signed by Kazakhstan at that moment. All Annexes of the convention are shortly described in Appendix 2.

Ports and terminals must provide facilities to collect residues, oily mixture, and garbage generated from the vessel. MARPOL states that contaminants cannot be discharged into the sea and that it shall be transferred to port reception facilities. It also says that port states shall ensure that there are enough port reception facilities throughout the area to help with convenience.

This Annex VI deals with air pollution and provides the standards for the marine diesel engines, exhaust gas cleaning system, fuel oil suitability. As was mentioned before in this chapter MARPOL Annex VI is not ratified by Kazakhstan. In 2017 from 13 to 15 of September, there was a meeting with the Ministry of $\mathrm{RKz}$ and IMO experts, where the implementation of MARPOL Annex VI was discussed. Currently, the Ministry of RKz is working on the ratification of Annex VI to MARPOL. The implementation of the requirements of MARPOL Annex VI will allow Kazakhstan to minimize the risk of pollution of the Caspian Sea 
from seagoing and protect the marine flora and fauna from environmental damage. The fuel used on board of ships must meet the requirements of MARPOL Annex VI Chapter 3 regulation 18 which addresses the composition of hydrocarbons to be used for combustion purposes. Their composition, must not exceed the sulfur content requirements (MARPOL Ch. 3, Reg. 14) and must not cause an engine to exceed the NOX emission limits (MARPOL Ch. 3, Reg. 13). For example, Marine Diesel Oil (MDO) can be used, as it meets those requirements.

\subsubsection{Initial IMO Strategy on Reduction of GHG Emissions from Ships} The "Third IMO GHG Study 2014" showed that GHG emissions from shipping in 2012 accounted for some $2.2 \%$ of anthropogenic CO2 emissions (Ebi et al., 2014). Additionally, the study established that such emissions could grow by between $50 \%$ and $250 \%$ by 2050 . In order to reduce GHG emissions, IMO's Marine Environment Protection Committee has adopted an initial strategy on the reduction of GHG emissions from ships, in April 2018. The initial strategy aims to reduce GHG emissions, by at least $50 \%$ by 2050 compared to 2008 . The strategy is divided into three phases (including short-, mid-, and long-term further measures). Some of these measures include:

- Considering the reduction of speed as a measure;

- Consider the use of on-shore power supply from renewable sources;

- Consider the development of activities addressing marine propulsion, alternative low-carbon, and zero-carbon fuels;

- Encourage and facilitate the adoption of other possible innovative emissions reduction mechanisms.

\subsection{Measures Taken by Other Companies Operating in the Caspian Sea}

In order to control the number of emissions which are produced onboard, special equipment to measure how much emissions the vessel emitted onboard can be used. For example, the Marine Environment Protection Committee developed so-called The Ship Energy Efficiency Plan (SEEMP), which is an operational measure that establishes a mechanism to improve the energy efficiency of a ship in a cost-effective manner (International Maritime Organization, 2011). The SEEMP also provides an approach for the companies to manage ship and fleet efficiency performance over time using, for example, the Energy Efficiency Operational Indicator as a monitoring tool. In compiling the SEEMP's, each vessel has to be provided with an automatic spreadsheet that can calculate amounts of NOx and SOx generated, based on the input of basic fuel consumption and voyage data.

Then, set the national air quality standards and the penalty for those who do not apply to these standards or if the level of emitted gases is more than required. For instance, the stakeholders of the Chevron Pembroke Marine Terminal set the regulation that those vessels which do not comply may face prose- 
cution or pay the penalty. In addition to this, the overall state of air quality should be controlled in the surrounding area. There could be used air quality monitoring stations for the observation on the existence of air pollution. For example, North Caspian Operating Company (NCOC) which is one of the leading company operating in the Caspian Sea and nearby, uses such stations in order to control the quality of air in all areas of its operations and then the Department of Ecological Monitoring Kazgidromet publishes monthly, quarterly and annual reports on the state of the environment that include an appendix of analyzed data from NCOC industrial air quality monitoring stations and surrounding area. These air quality monitor stations are located nearly with Atyrau city. These stations operate $24 / 7$ to measure the atmospheric levels of various compounds and collect weather data.

Besides, there could be conducted surveys on the state of seawater, sea bottom, flora and the living conditions of fauna. For instance, NCOC implements extensive environmental monitoring programs in order to analyze the chemical composition of seawater and bottom sediments and to study fish, benthos and plankton populations. They conduct biyearly surveys where covers weather conditions, water quality and bottom sediments quality (North Caspian Operating Company, 2015, 2016, 2017, 2018).

\subsection{Measures Taken by Developed International Ports}

There lots of developed countries which strive to achieve better environmental conditions for the port areas. One of the significant projects which could help to minimize the pollution from ships in port areas is shore power supply. In order to minimize the air pollution and noise from vessels at ports and terminals shore power can be used by ships by plugging into the local electricity grid and turning off auxiliary engines while at dock. While using a shore power supply, auxiliary systems such as air conditioning, lighting, and crew onboard can use energy from the local electrical grid. Shore power typically produces zero onsite emissions. The power generation plant which supplies electricity to shore power applications may or may not be within the confines of the port and can be located outside those areas.

The power generated onshore, which can be from an electric utility company or from possible external remote generator (these generators may be powered by diesel or renewable energy sources such as wind or solar), via power cables (Figure 2) transmit the power to the onboard installations which consist of shore-to-ship power panel and fully automated power transfer.

This technology was implemented in such countries as Netherland (Rotterdam), Sweden (Gothenburg, Ystad), Malta (Delimara), China (Dalian), Italy (Fincantieri), Costa Rica (Moin). According to Roberto Bernacchi (Bernacchi, 2017), who is shore-to-ship power and smart ports global product manager, and other scientists (Radwan et al., 2019), the benefits are as follows:

- GHG emissions reduced by $98 \%$;

- Less noise and vibrations; 


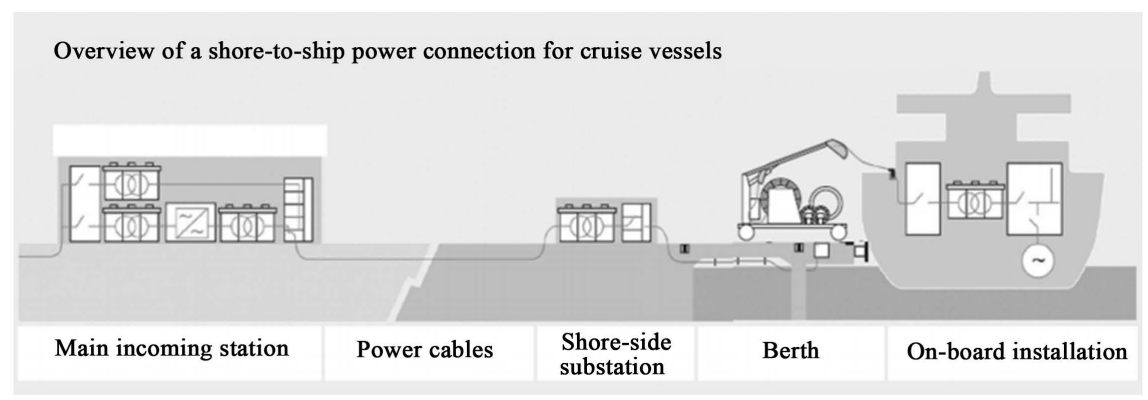

Figure 2. Shore power connections. Source: (Bernacchi, 2017).

- A better environment for passengers, crew, dockworkers and local residents;

- Reduction of the fleet's fuel consumption;

- Improve the quality of life near the port.

\subsection{Concluding Marks}

The protection of the environment is one of the main concerns for shipping industry nowadays. It is necessary for vessels operating in the TCOF area to comply with regulations such as MARPOL and local requirements in order to maintain all procedures safely and without any harm to the surrounding area. In addition to this, the area must be protected from various air pollutants, where the shore power could be used. It will not only minimize the emissions from ships but also protect the local habitats from noise pollution, vibration and considerably improve the quality of life near the terminal. Those above-mentioned suggestions will help to maintain great environmental protection and prevent further effects of pollution which were described in Section 3 of this work.

\section{Overall Conclusion and Recommendations}

The environmental pollution of port areas is one of the considering problems nowadays, as the shipping can pollute not only the environment but also make harm to the surrounding habitat and nature. And that's why the government should try to prevent an oil spill during loading operation of the tanker, as it happened to the tanker "Islam Saparli" in December 2001 in the port of Aktau of the Caspian Sea (Zonn, 2005).

During the research, the causes of pollution by ships in the TCOF area were identified, which can include pollution from the diesel engine, GHG emissions, noise, various spills from ships, incineration, human factor, etc. According to the Third IMO GHG Study 2014, "GHG emissions from shipping in 2012 accounted for some $2.2 \%$ of anthropogenic $\mathrm{CO}_{2}$ emissions. Additionally, the study established that such emissions could grow by between $50 \%$ and $250 \%$ by 2050 " (Merk, 2014). And this is the only pollution from GHG emissions. Consequently, from these reasons, the impacts of pollution sources were identified. From air pollution, various health diseases such as cancer, increased susceptibility to respiratory infections, decreased lung function, etc. can arise. Besides, the noise pollution can disturb local fauna, and various spills from ships can danger the 
nature and kill sea habitats.

The research has shown that the governments and involved companies who operate in the TCOF area set their own regulations for the prevention of pollution. In addition to this, vessels must follow international and national regulations. The short interview taken from Tengizchevroil authorities has shown that they provide all means possible for vessels operating in the TCOF area to minimize the pollution. Summing up the studied information, for the purpose of this work, the various conventions aimed at the prevention of pollution by ships were researched and the measures taken by other ports were identified. This leads us directly to the recommendations.

During the research process, the authors studied the problem in the maritime industry, particularly the problem related to the environmental pollution in ports and terminals, specifically the TCOF area of FGP. Section 3 of this work described the main issues which should be solved and improved. The recommendations with possible solutions are provided by analyzing the current situation in the TCOF area regarding environmental protection and studying different regulations on the prevention of pollution from ships:

1) The ratification of MARPOL Annex VI by Kazakhstan. The implementation of the requirements of MARPOL Annex VI will allow Kazakhstan to minimize the risk of pollution of the Caspian Sea from seagoing vessels, particularly minimize air pollution.

2) Implementation of IMO's Initial strategy for the reduction of GHG emissions from ships. If this strategy will be implemented, then the reduction of GHG emissions could grow by at least $50 \%$ by 2050 . Furthermore, this could prevent further effects of GHG emissions.

3) Set the penalty for the pollution of the environment and not complying with the regulations. This will allow minimizing the pollution as the vessels will strictly follow the regulations and make better observance of the environment.

4) Conduct surveys on the state of seawater, sea bottom, flora and the living conditions of local habitats. This will allow monitoring and analyzing the chemical composition of seawater and bottom sediments, and study fish, other fauna population.

5) Use air quality control stations and make a better observation to control the state of the surrounding air. This could allow monitoring the state of air and compare it on the existence of various atmospheric compounds.

6) Use the shore power supply as the electrical source. When the shore supply will be used, the vessel's auxiliary engines will be switched off. This will lead to the reduction of GHG emissions, noise pollution, vibration, and fuel consumption by the vessels. Furthermore, it could improve the quality of life near the TCOF area.

\section{Author Contribution Statements}

All the authors have contributed equally to this paper. Altynbek Smailkhan supervised the project. Altynbek Smailkhan and Kamila Nukuyeva collected the 
data, wrote the manuscript, provided the recommendations and contributed to the final manuscript. Kamila Nukuyeva interviewed the representatives of the Kazakh oil company "Tengizchevroil". Sarvar Khalikov designed the project, provided critical feedback and didn't participate in the final evaluation.

\section{Acknowledgements}

This research was undertaken as a part of the two programs: graduate program in Transport Planning \& Management of Shanghai Maritime University; undergraduate program in Nautical Sciences of Kazakhstan Maritime Academy. The authors gratefully acknowledge the support from Kirill Samaray, lecturer of Kazakhstan Maritime Academy, for review. In addition, we would love to thank Alco E. Weeke, senior lecturer of STC Group, for guidance during all the process of writing this paper.

\section{Conflicts of Interest}

The authors declare no conflicts of interest regarding the publication of this paper.

\section{References}

Bernacchi, R. (2017). Portfolio Overview. Shore-to-Ship Power \& Smart Ports. https://library.e.abb.com/public/ef42205027df40fcaea5548681ea74ba/S2SP SP Externa 1_new brand 19042017.pdf

Dmitrieva, L., Kondakov, A. A., Oleynikov, E., Kydyrmanov, A., Karamendin, K., Kasimbekov, Y., Goodman, S. J. et al. (2013). Assessment of Caspian Seal By-Catch in an Illegal Fishery Using an Interview-Based Approach. PLoS ONE, 8, e67074.

https://doi.org/10.1371/journal.pone.0067074

Ebi, K. L., Hallegatte, S., Kram, T., Arnell, N. W., Carter, T. R., Edmonds, J., Zwickel, T. et al. (2014). A New Scenario Framework for Climate Change Research: Background, Process, and Future Directions. Climatic Change, 122, 363-372.

https://doi.org/10.1007/s10584-013-0912-3

International Maritime Organization (2011). Energy Efficiency Measures. http://www.imo.org/en/OurWork/Environment/PollutionPrevention/AirPollution/Pag es/Technical-and-Operational-Measures.aspx

Julian, M. (2000). MARPOL 73/78: The International Convention for the Prevention of Pollution from Ships. Maritime Studies, 2000, 16-23. https://doi.org/10.1080/07266472.2000.10878605

Kantharia, R. (2019). MARPOL (The International Convention for Prevention of Marine Pollution for Ships): The Ultimate Guide.

https://www.marineinsight.com/maritime-law/marpol-convention-shipping

Mackay, A. (2008). Climate Change 2007: Impacts, Adaptation and Vulnerability. Contribution of Working Group II to the Fourth Assessment Report of the Intergovernmental Panel on Climate Change. Journal of Environment Quality, 37, 2407. https://doi.org/10.2134/jeq2008.0015br

Merk, O. (2014). Shipping Emissions in Ports. The International Transport Forum's Discussion Paper. https://doi.org/10.1787/5jrw1ktc83r1-en

North Caspian Operating Company (2015). Sustainability Report 2015. 
https://www.ncoc.kz/Documents/Sustainability report 2015 en.pdf

North Caspian Operating Company (2016). Sustainability Report 2016. https://www.ncoc.kz/en/sustainability/2016

North Caspian Operating Company (2017). Sustainability Report 2017. https://www.ncoc.kz/en/sustainability/2017? section=1

North Caspian Operating Company (2018). Sustainability Report 2018. https://www.ncoc.kz/en/sustainability/2018

Radwan, M. E., Chen, J., Wan, Z., Zheng, T., Hua, C., \& Huang, X. (2019). Critical Barriers to the Introduction of Shore Power Supply for Green Port Development: Case of Djibouti Container Terminals. Clean Technologies and Environmental Policy, 21, 1293-1306. https://doi.org/10.1007/s10098-019-01706-Z

Sheppard, C. (2018). World Seas: An Environmental Evaluation: Volume III: Ecological Issues and Environmental Impacts. Cambridge, MA: Academic Press. https://doi.org/10.1016/B978-0-12-805068-2.10000-2

The UK Government Darwin Initiative, \& The Kazakh Fisheries Research and Production Centre (2006). Caspian Seal Project. http://www.caspianseal.org

U.S. Energy Information Administration (2019). Electricity Explained. Electricity in the United States. https://www.eia.gov/energyexplained/electricity/electricity-in-the-us.php

U.S. Environmental Protection Agency (2018). Ports Primer: 7.2 Air Emissions. https://www.epa.gov/community-port-collaboration-and-capacity-building/ports-prim er-72-air-emissions

Vidal, J. (2009). Health Risks of Shipping Pollution Have Been "Underestimated". The Guardian.

Zonn, I. S. (2005). Environmental Issues of the Caspian. In G. K. Andrey, \& N. K. Aleksey (Eds.), The Caspian Sea Environment (pp. 223-242). Berlin: Springer.

https://doi.org/10.1007/698 5012 


\section{Appendix 1. Causes and Effects}
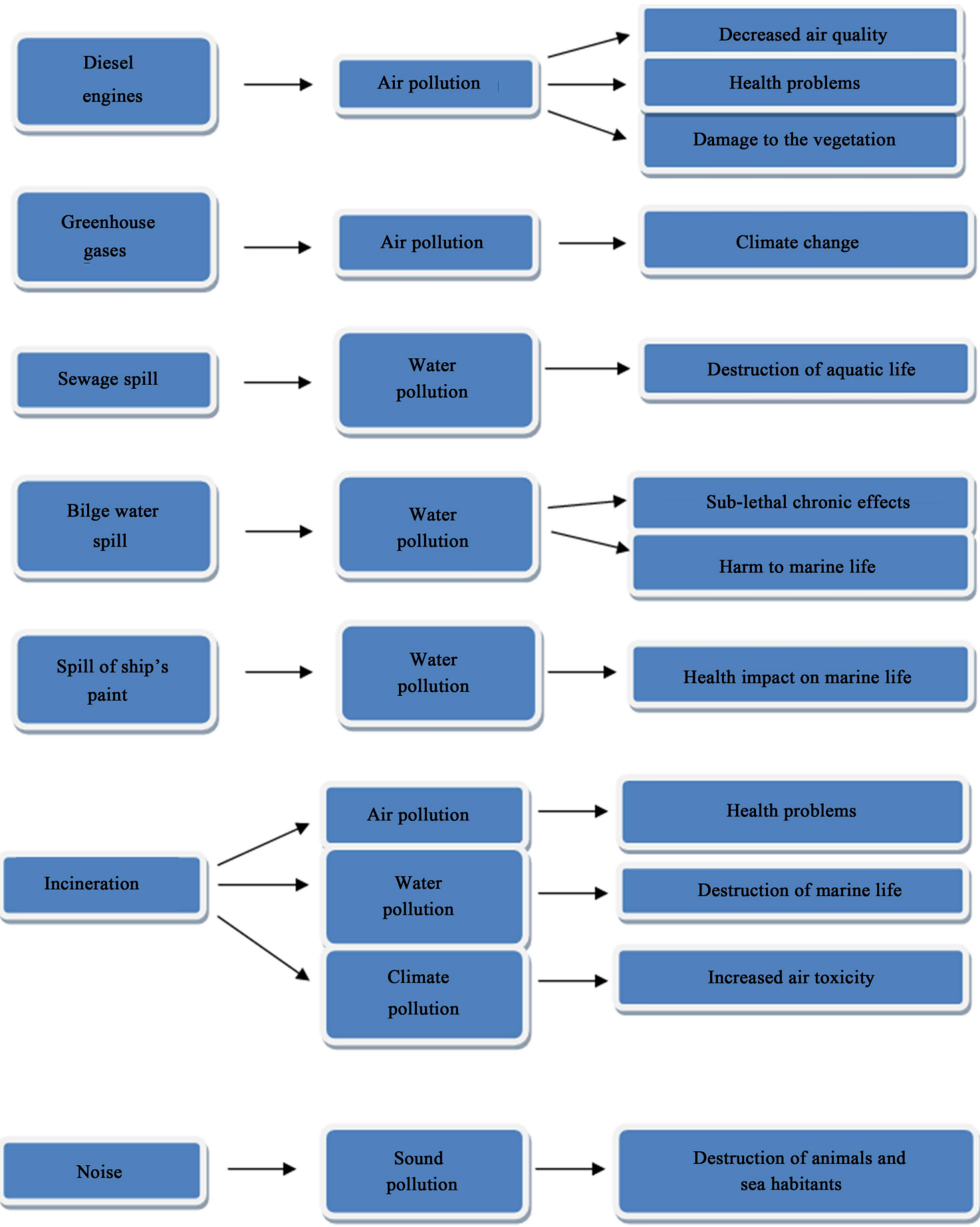

Water

pollution

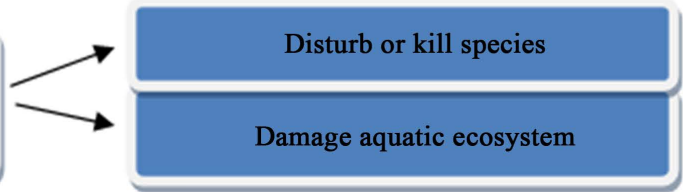


Appendix 2. MARPOL Annexes Short Description. Source: (Julian, 2000; Kantharia, 2019)

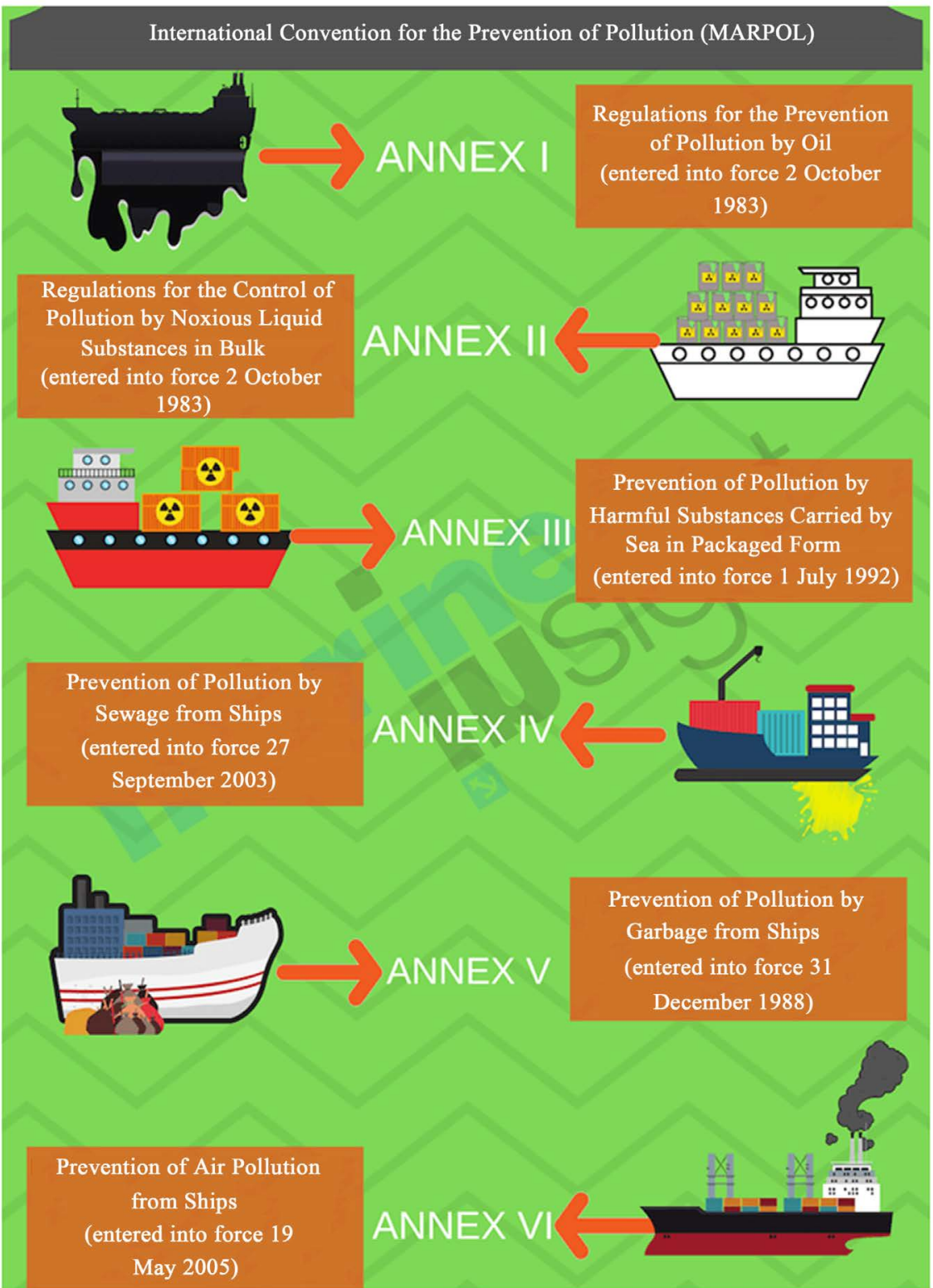

